Giriwijoyo, S dan Komariyah, L. 2002. Olahraga Kesehatan dan Kesegaran Jasmani pada Lanjut Usia. Bandung. Fakultas Pendidikan Olahraga dan Kesehatan Universitas Pendidikan Indonesia

Goodman, A. 2001. The Economics of Health and Health Care Third edition. New Jersey: Upper Saddle River.

Machfoed. 2005. Perilaku Sehat dalam Prinsip-prinsip Kesehatan. Yogyakarta: UGM.

Mubarok, W.I, Chayatin. N, Rozikin, K., Supradi. 2007. Promosi Kesehatan. Yogyakarta: Graha Ilmu.

Simons-Morton B.G., Greene, W.H. and Gottlieb, N.H. 1995. Introduction to Health Education and Health Promotion. Second edition. Waveland Press, Inc. Illinois, USA.

Suara Merdeka Cyber News. 2006. Tetap Fit di Usia Tua. Suara Merdeka, 23 Agustus 2006. Availabel on line at www.suaramerdeka.com

Sumiarto. 1993. "Perumahan dan Pemukiman, Sejarah dan Tantangan di Depan". Forum Perencanaan Pembangunan. Vol 1 Nomor 2, Desember 1993, Yogyakarta: UGM

Wahyuni, Dwi. 2003. Identifikasi Kebutuhan Lansia. Penelitian. Puslitbang KS-PKP BKKBN. Available on line at http://www.bkkbn.go.id/ditfor/research_detail.php?rchid $=14$.

Widoyono. 2008. Penyakit Tropis: Epidemiologi, Penularan, Pencegahan, dan Pemberantasannya. Semarang: Penerbit Erlangga.

\section{IMPLEMENTASI TANGGUNG JAWAB SOSIAL \\ PERUSAHAAN DALAM BENTUK PROGRAM \\ KEMITRAAN DAN BINA LINGKUNGAN}

Oleh:

Chandra Dewi Puspitasari

Universitas Negeri Yogyakarta

\section{Abstract}

This study is aims to determine the implementation of corporate social responsibility in the form of "Program Kemitraan dan Bina Lingkungan (PKBL) at PTMadubaru and the obstacles, and to determine the impact of the implementation of corporate social responsibility, both for companies and for local con on and for local communities who were targets PKBL. This study is a descriptive study with qualitative approach. Subject of study is determined by purposive and snowball technique. The data was collected by interviews and document studies. Furthermore, the data were analyzed using inductive analysis. The results suggest that corporate social responsibility that is implemented is still largely in the form of momentary fulfillment, not to the aspect of sustainability as intended in community development. Obstacles encountered in implementing PKBL is difficult to find small businesses that fit with the company's business activities, the difficulty of finding good business-minded and responsible, and not compatibles PKBL budget allocation for the activity by the number of requests, so the funds are rolled still considered small by the comber of requests, so the funds are rolled sill considered small by the community. The impact of the implementation is not optmal PKBL felt, because, although PT Madubaru has implemented PKBL in varions activities and felt there was a good relationship with the local community that is created through the implementation PKBL, but on the other side of the perceived benefit of trained partners and target communities to the extent not empower society.

Keywords: corporate social responsibility, $P K B L$

\section{PENDAHULUAN}

Salah satu isu penting yang menjadi perhatian dalam dunia usaha hingga saat ini adalah tanggung jawab sosial perusahaan 
(Corporate Social Responsibility/CSR). Konsep tanggung jawab sosial perusahaan sendiri muncul sebagai akibat ketidakpercayaan masyarakat terhadap korporasi. Masyarakat menganggap korporasi sebagai pihak yang selalu mengeruk keuntungan tanpa memperdulikan kondisi masyarakat maupun lingkungan sekitarnya (Gunawan Widjaja dan Yeremia Ardi Pratama, 2008 11).

Pemikiran John Elkington (dalam Gunawan Widjaja dan Yeremia Ardi Pratama, 2008: 33) telah mengembangkan konsep triple bottom line dalam istilah economic prosperity, environmental quality, dan social justice. Apabila suatu perusahaan ingin mempertahankan kelangsungan hidupnya, maka perusahaan harus memperhatikan "3 P". Selain mengejar keuntungan (profit), perusahaan juga harus memperhatikan dan terlibat pada pemenuhan kesejahteraan masyarakat (people) serta turut berkontribusi aktif dalam menjaga kelestarian lingkungan (planet).

Sampai saat ini belum ada keseragaman mengenai pengertian tanggung jawab sosial perusahaan. Pengertian tanggung jawab sosial perusahaan yang telah dituangkan dalam ketentuan perundang-undangan pun ternyata belum mempunyai bahasa dan makna yang sama terhadap tanggung jawab sosia perusahaan tersebut (Azheri dan Isa Wahyudi, 2008: 31). Pada tataran implementasi, tanggung jawab sosial perusahaan pada dasarnya merupakan kontribusi aktif perusahaan dalam rangka ikut serta mewujudkan pembangunan berkelanjutan (sustainable development). Namun, seringkali dalam praktik kegiatan tanggung jawab sosial perusahaan ini banyak perusahaan mempersamakan dengan derma, sehingga dengan memberikan sejumlah uang tertentu kepada masyarakat di sekitar perusahaan sudah dianggap telah melaksanakan tanggung jawab sosial kepada masyarakat. Padahal, konsep tanggung jawab sosial perusahaan tidak sama dengan derma. Derma sifatnya lebih spontan, dan kurang memiliki efek jangka panjang bagi pembangunan masyarakat.
Dimasukkannya konsep tanggung jawab sosial perusahaan pada berbagai peraturan perundang-undangan membuat konsep tanggung jawab sosial perusahaan bukan lagi "sekedar" kewajiban moral bagi perusahaan. Di Indonesia, kebijakan mengenai tanggung jawab sosial perusahaan diatur dalam Undang-Undang Nomor 40 Tahun 2007 tentang Perseroan Terbatas (UU PT) pada pasal 74 ayat (1-4), pasal 15 Undang-Undang Nomor 25 Tahun 2007 tentang Penanaman Modal (UU PM), dan Undang-Undang Nomor 19 Tahun 2003 tentang BUMN yang ditindaklanjuti dengan terbitnya Keputusan Menteri BUMN Nomor Kep236/MBU/2003 tentang Program Kemitraan Badan Usaha Milik Negara dengan Usaha Kecil dan Bina Lingkungan. Melalui kebijakan tersebut pemerintah mewajibkan BUMN untuk menyisihkan sebagian labanya untuk pemberdayaan masyarakat yang implementasinya ditindaklanjuti dengan dikeluarkannya Surat Edaran Menteri BUMN Nomor SE-433/MBU/2003 tentang Petunjuk Pelaksanaan Program Kemitraan Badan Usaha Milik Negara dengan Usaha Kecil dan Bina Lingkungan.

PT Madubaru sendiri sejak tahun 2004 hingga saat ini kepemilikan sahamnya ada di tangan Sri Sultan Hamengkubuwono X (Kraton Yogyakarta) sebanyak 65\% dan sisanya sebanyak $35 \%$ ada di tangan PT Rajawali Nusantara Indonesia (PT RNI). Terdapatnya sebagian saham ditangan BUMN menjadi alasan bahwa perusahaan tersebut melaksanakan tanggung jawab sosial dengan istilah dan dalam bentuk PKBL sebagaimana diatur oleh peraturan perundang-undangan yang berlaku bagi BUMN. BUMN merupakan agent of development. Oleh karena itu, BUMN harus mampu menjadi penggerak bagi pembangunan masyarakat di sekitarnya, sehingga kegiatan tanggung jawab sosial perusahaan yang dilakukan tersebut diharapkan dapat mewujudkan pengembangan masyarakat yang berkelanjutan (sustainable community development)

Melalui pelaksanaan tanggung jawab sosial perusahaan, diharapkan terjadi peningkatan partisipasi perusahaan untuk 
memaksimalkan potensi masyarakat sekitar. Terlebih lagi BUMN telah memiliki instrumen pemaksa berupa ketentuan pelaksanaan PKBL. Instrumen pemaksa tersebut harapannya mampu membawa BUMN untuk berperan lebih besar dalam memberikan bantuan-bantuan sosial dibandingkan dengan perusahaanperusahaan swasta yang ada, sehingga pemberdayaan kondisi sosial masyarakat setempat dapat lebih optimal.

Selanjutnya dikemukakan beberapa permasalahan sebaga berikut: (1) bagaimanakah implementasi tanggung jawab sosial perusahaan dalam bentuk PKBL yang dilakukan oleh PT Madubaru?; (2) Hambatan-hambatan apa saja yang dihadapi oleh PT Madubaru dalam mengimplementasikan tanggung jawab sosial dalam bentuk PKBL tersebut?; dan (3) Bagaimanakah dampak implementasi tanggung jawab sosial perusahaan dalam bentuk PKBL tersebut, baik bagi perusahaan maupun bagi masyarakat sekitar yang menjadi sasaran PKBL?

\section{Metode Penelitian}

Jenis penelitian ini adalah penelitian deskriptif dengan pendekatan kualitatif yang bertujuan untuk mendapatkan gambaran yang jelas mengenai implementasi tanggung jawab sosial perusahaan dalam bentuk PKBL beserta hambatannya dan dampak implementasi tanggung jawab sosial perusahaan dalam bentuk PKBL tersebut, baik bagi perusahaan maupun masyarakat sekitar.

Penentuan subjek penelitian dalam penelitian in dilakukan dengan menggunakan teknik purposive. Adapun kriteria yang digunakan untuk menentukan subjek penelitian ini adalah pihak-pihak yang memiliki pengetahuan dan pengalaman serta keterlibatan dalam implementasi tanggung jawab sosial PT Madubaru. Subjek penelitian yang lain ditentukan dengan teknik snowball, yaitu kepada usaha kecil yang telah menjadi mitra binaan minimal selama 6 (enam) bulan dan diutamakan berkedudukan di sekitar PT Madubaru. Sedangkan untuk mewakili masyarakat sasaran bina lingkungan, peneliti memilih beberapa warga masyarakat yang bertempat tinggal di sekitar PT Madubaru dan mengalami dampak negatif dari keberadaan PT Madubaru, serta mengetahui implementasi tanggung jawab sosial PT Madubaru dalam bentuk program bina lingkungan.

Teknik pengumpulan data dilakukan melalui wawancara dan dokumentasi. Analisis data dilakukan dengan analisis induktif. Selanjutnya validasi data dilakukan dengan cross check data.

\section{PEMBAHASAN}

Program kemitraan adalah program yang dilaksanakan untuk meningkatkan kemampuan usaha kecil agar menjadi tangguh dan mandiri melalui pemanfaatan dana bagian dari laba BUMN. Usaha kecil yang dikatakan sebagai kegiatan ekonomi rakyat yang berskala kecil harus memenuhi beberapa kriteria sebagaimana disebutkan pada Pasal 3 Keputusan Menteri BUMN Nomor Kep-236/MBU/2003 tentang Program Kemitraan Badan Usaha Milik Negara dengan Usaha Kecil dan Bina Lingkungan. Selain itu, berdasarkan Surat Edaran Menteri BUMN Nomor SE433/MBU/2003 tentang Petunjuk Pelaksanaan Program Kemitraan Badan Usaha Milik Negara dengan Usaha Kecil dan Bina Lingkungan, bahwa yang menjadi prioritas pada program kemitraan ini adalah usaha kecil yang belum memiliki kemampuan akses perbankan, dan tidak memiliki kaitan usaha dengan BUMN pembina, namun diupayakan ke arah terwujudnya keterkaitan usaha.

Sampai tahun 2010 usaha kecil dan atau koperasi yang pernah menjadi mitra binaan PT Madubaru sebanyak 229 mitra binaan. Namun demikian, saat ini hanya tinggal 176 mitra binaan saja yang masih aktif menjadi mitra binaan PT Madubaru. Mitra binaan tersebut memiliki jenis usaha yang bermacam-macam 
meliputi usaha kerajinan, perdagangan, peternakan, perikanan, dan jasa.

Bentuk program kemitraan yang dilakukan oleh PT Madubaru meliputi (1) Pinjaman Jangka Panjang, yaitu pinjaman untuk membiayai modal kerja dan atau pembelian aktiva tetap dalam rangka meningkatkan produksi dan penjualan, (2) Pinjaman Jangka Pendek (Khusus), yaitu pinjaman yang digunakan untuk membiayai kebutuhan dana pelaksanaan kegiatan usaha mitra binaan yang bersifat jangka pendek dalam rangka memenuh pesanan dari rekanan usaha mitra binaan, dan (3) Hibah, yang digunakan untuk membiayai kegiatan yang terkait dengan manajerial yaitu seperti pelatihan dan yang terkait dengan pemasaran, yaitu seperti pameran dan promosi produk unggulan mitra binaan.

Pada bentuk pinjaman, PT Madubaru mewajibkan penyerahan agunan sebagai rasa tanggung jawab calon mitra binaan terhadap pinjaman yang diterima. Agunan yang diserahkan disesuaikan dengan jumlah pinjaman. Minimal taksirannya sama dengan nilai pinjaman. Usaha kecil yang menjadi mitra binaan biasanya mengagunkan BPKB atau sertifikat tanah bangunan. Selain itu jaminan dapat pula berupa peralatan/barang yang dibeli dari dana pinjaman secara fiducia. Namun demikian, berdasarkan data yang diperoleh penulis di lapangan menunjukkan bahwa sebagian usaha kecil yang menjadi mitra binaan PT Madubaru menyerahkan agunan dibawah nilai pinjaman. Hal tersebut disebabkan adanya faktor kepercayaan antara pemilik usaha kecil dan tim dari Unit PKBL PT Madubaru.

Demikian pula pada pelaksanaan Perjanjian Kemitraan Pada praktiknya, ada beberapa ketentuan di dalam perjanjian tersebut yang belum dijalankan secara optimal. Mitra binaan yang menjadi responden pada penelitian ini menyebutkan bahwa pembinaan terhadap peningkatan mutu dan kapasitas penjualan, administrasi/akuntansi, manajemen, dan diklat/training, yang seharusnya dilakukan oleh PT Madubaru sebagaimana disebutkan pada Pasal 2 Perjanjian Kemitraan, belum optimal dan belum seluruh mitra binaan tersebut pernah mendapatkan pembinaan tersebut. Selain itu, beberapa mitra binaan yang terlambat membayarkan angsuran tidak dikenai denda sebagaimana telah ditentukan dalam perjanjian, yaitu sebesar 5\% dari jumlah yang harus dibayarkan untuk setiap bulan. Mitra binaan yang terlambat membayar angsuran dapat membayarkan angsuran pada bulan berikutnya tanpa dikenai denda. Tidak lancarnya pembayaran angsuran dan bunga juga terjadi. Selanjutnya akan dilakukan penjadwalan ulang (rescheduling) terhadap pinjaman tersebut.

Selain direalisasikan dalam bentuk pinjaman, program kemitraan juga dapat direalisasikan dalam bentuk hibah. Hibah hanya diperuntukkan bagi mitra binaan saja. Dana hibah yang dikeluarkan maksimal 20\% (dua puluh persen) dari jumlah alokasi pinjaman. Dana hibah dimanfaatkan untuk pelaksanaan kegiatan pelatihan, pameran dan promosi produk. Kegiatan-kegiatan tersebut belum diagendakan secara rutin setiap tahunnya oleh PT Madubaru.

Penulis melihat bahwa program kemitraan yang diimplementasikan oleh PT Madubaru masih didominasi oleh pengguliran dana program kemitraan setiap tahunnya melalui pinjaman dengan pembinaan yang tidak secara rutin dan optimal bagi para mitra binaan. Padahal, pembinaan sebagaimana telah disepakati dalam perjanjian kemitraan sangat dibutuhkan oleh mitra binaan. Pembinaan terhadap peningkatan mutu dan kapasitas penjualan, administrasi/akuntansi, manajemen, dan diklat/training merupakan bagian dari peningkatan produktivitas sebuah kegiatan usaha, di samping terdapat bantuan pinjaman dana sebagai tambahan modal usaha. Melalui peningkatan produktivitas itulah sesungguhnya diharapkan usaha kecil dapat mandiri dan berkembang, sehingga tujuan untuk memperluas lapangan kerja, memperluas kesempatan berusaha dan memberdayakan masyarakat dapat dicapai. 
Harapannya kegiatan dari implementasi tanggung jawab sosial perusahaan dalam bentuk program kemitraan tersebut dapa menghasilkan dampak yang positif tidak hanya secara internal tetapi juga eksternal perusahaan. Harmonisasi antara perusahaan, masyarakat sekitar serta lingkungan sekitar akan menjadi sebuah investasi jangka panjang bagi pihak-pihak tersebut.

Selain hal tersebut di atas, penulis melihat bahwa PT Madubaru perlu untuk melakukan penataan kembali atas implementasi tanggung jawab sosial perusahaan dalam bentuk program kemitraan ini. Hal tersebut sangat tampak pada pelaksanaan program kemitraan yang selama ini berlangsung, terutama terkait dengan kepatuhan para pihak terhadap perjanjian kemitraan.

Selain dalam bentuk program kemitraan sebagaimana dipaparkan di atas, PKBL juga diwujudkan dalam bentuk program bina lingkungan, yaitu program pemberdayaan kondisi sosia masyarakat oleh BUMN di wilayah usaha BUMN tersebut melalui pemanfaatan dana dari bagian laba BUMN. Masyarakat sasaran program bina lingkungan meliputi masyarakat yang bertempa tinggal di sekitar perusahaan atau masyarakat yang berada di wilayah kerja pabrik (tidak di sekitar perusahaan namun dekat dengan perkebunan tebu yang dikelola perusahaan). Program bina lingkungan PT Madubaru diwujudkan dalam bentuk pendidikan masyarakat, kesehatan masyarakat, pengembangan sarana umum penyediaan sarana ibadah, bantuan bencana alam, dan pelestarian alam. Tidak setiap bentuk dari program bina lingkungan diadakan untuk setiap tahun, ada pula yang diadakan dengan menyesuaikan kebutuhan atau permintaan seperti misalnya pengembangan sarana umum, pelayanan kesehatan, bantuan bencana alam, dan pelestarian alam. Program bina lingkungan yang dilakukan PT Madubaru ternyata tidak hanya menjadi tugas Unit PKBL saja tetapi dalam beberapa hal Unit PKBL juga melakukan koordinasi dengan Unit Pengelolaan Limbah dan Lingkungan (PLL) dalam melaksanakan tanggung jawab sosial perusahaan. Koordinas tersebut dilakukan untuk menilai kelayakan masyarakat sasaran yang akan diberikan program bina lingkungan.

Dari beberapa realisasi program bina lingkungan tersebut, ada yang berkaitan secara langsung dengan community development yaitu penyediaan sarana umum, khususnya yang mendukung kegiatan perekonomian masyarakat setempat, seperti misalnya pengerasan jalan dan pembuatan jembatan. Bantuan pengadaan fasilitas tersebut dirasakan masyarakat sasaran bina lingkungan sangat membantu dalam melancarkan transportasi dalam kegiatan perekonomian masyarakat sehari-hari.

Pada buku "Pedoman CSR Bidang Lingkungan" yang diterbitkan oleh Kementerian Lingkungan Hidup dan Universitas Trisakti (2011:14-22) disebutkan bahwa alternatif bidang kegiatan tanggung jawab sosial bidang lingkungan yang dapat dilakukan oleh perusahaan antara lain adalah cleaner production (produksi bersih), eco office (kantor ramah lingkungan), konservasi energi dan sumber daya alam (SDA), pengelolaan sampah melalui $3 \mathrm{R}$ (reuse, reduce, recycle), renewable energy, adaptasi perubahan iklim, dan pendidikan lingkungan hidup.

Mencermati paparan mengenai implementasi program bina lingkungan tersebut di atas, maka penulis melihat bahwa implementasi program bina lingkungan dapat dikatakan masih didominasi oleh kegiatan yang sifatnya charity atau derma (bantuan), namun derma tersebut imperatif karena terdapat ketentuan khusus bagi BUMN sebagai instrumen pemaksa. Instrumen pemaksa tersebut harapannya mampu membawa BUMN untuk berperan lebih besar dalam memberikan bantuanbantuan sosial dibandingkan dengan perusahaan-perusahaan swasta yang ada, sehingga pemberdayaan kondisi sosial masyarakat setempat dapat lebih optimal.

PT Madubaru selama ini masih kesulitan untuk mencari usaha kecil yang memiliki keterkaitan usaha dengan usaha pokok PT Madubaru. Dari 176 usaha kecil yang menjadi mitra binaan PT Madubaru hanya 1 (satu) usaha kecil yang terkait dengan kegiatan 
operasional PT Madubaru, yaitu "Nogogini". "Nogogini" merupakan mitra binaan milik Ny. Sulistyowati yang beralamat di Padokan, Tirtonirmolo, Kasihan, Bantul. Usaha tersebut bergerak di sektor dagang berupa penyediaan kayu untuk bahan bakar mesin di PT Madubaru. Berdasarkan SE Menteri BUMN Nomor 433/MBU/2003 dikatakan bahwa program kemitraan dapat dilakukan kepada usaha kecil yang tidak memiliki kaitan usaha dengan BUMN pembina, namun diupayakan ke arah terwujudnya keterkaitan usaha. Oleh karena itu, PT Madubaru masih dapa bermitra dengan usaha kecil yang kegiatan usahanya di berbagai sektor, seperti dagang, industri, jasa, ternak, pertanian, dan perikanan.

Hambatan lain yang dihadapi adalah tidak mudahnya mencari pelaku usaha yang memiliki sikap mental yang baik dan bertanggung jawab dengan komitmen pada kegiatan kemitraan. Selain hal tersebut, terbatasnya anggaran juga menjadi hambatan bagi pelaksanaan tanggung jawab sosial perusahaan dalam bentuk PKBL bagi PT Madubaru. Dalam kondisi tertentu besaran alokas dana untuk program bina lingkungan sesungguhnya dapat ditentukan lain dengan persetujuan RUPS, sehingga dana yang dikucurkan akan membawa manfaat bagi masyarakat sekitar.

PT Madubaru menyadari bahwa keberadaannya di tengahtengah masyarakat mempunyai arti bahwa PT Madubaru juga merupakan bagian dari masyarakat itu sendiri. Oleh karena itu, menjalin hubungan yang harmonis dengan masyarakat sekitar sudah seharusnya dilakukan. PT Madubaru juga berupaya memperoleh dukungan dari masyarakat. Tanpa adanya dukungan dari masyarakat maka eksistensi sebuah perusahaan akan sulit dipertahankan.

Tanggung jawab sosial perusahaan dalam bentuk PKBL menjadi salah satu cara untuk mengangkat citra (image) perusahaan. Gejolak sosial akibat benturan kepentingan antara masyarakat dan PT Madubaru dapat ditekan melalui adanya citra yang baik tersebut. Menurut penulis, citra yang baik merupakan salah satu syarat pendukung untuk melancarkan produktivitas perusahaan. Perusahaan yang secara finansial sangat baik tidak selalu menjamin perusahaan tetap dapat eksis dan berkelanjutan. Masyarakat memiliki "power" yang secara tidak langsung dapat mempengaruhi eksistensi dan keberlangsungan perusahaan. Dalam jangka panjang, citra positif perusahaan akan mengangkat reputasi perusahaan di mata masyarakat. Reputasi yang baik akan melanggengkan eksistensi perusahaan dalam jangka panjang.

Parameter keberhasilan dari implementasi tanggung jawab sosial perusahaan dalam bentuk PKBL yang dilakukan oleh PT Madubaru adalah adanya manfaat yang dirasakan oleh masyarakat dari kegiatan PKBL. Manfaat tersebut dapat diketahui dari timbal balik yang ditunjukkan oleh masyarakat sekitar, yaitu melalui simpati dan dukungan masyarakat atas keberadaan PT Madubaru.

Pemberdayaan masyarakat termasuk masyarakat Usaha Mikro, Kecil, Menengah dan Koperasi tidak hanya menjadi tugas dan tanggung jawab pemerintah pusat dan daerah, namun juga menjadi tugas dan tanggung jawab dunia usaha, sebagaimana dijelaskan pada Pasal 7 Undang-Undang Nomor 20 Tahun 2008 tentang Usaha Mikro, Kecil dan Menengah, bahwa dunia usaha (corporation) berperan serta menumbuhkan iklim usaha kondusif.

Mitra binaan menyebutkan bahwa dana pinjaman yang telah diberikan oleh PT Madubaru sangat membantu usaha yang mereka miliki. Meskipun beberapa mitra belum mendapatkan pembinaan dalam beberapa hal seperti pembinaan terhadap mutu dan kapasitas penjualan, pembinaan administrasi/akuntansi dan pembinaan manajemen. Sedangkan pada program bina lingkungan yang dilaksanakan oleh PT Madubaru yang bertujuan memberdayakan kondisi sosial masyarakat setempat juga dirasakan masyarakat cukup membantu. Meskipun dana yang diberikan masih dirasa cukup kecil karena anggaran untuk program bina lingkungan yang tidak sepadan dengan besarnya kebutuhan/permintaan. 
Berdasarkan paparan mengenai dampak yang dirasakan mitra binaan dan masyarakat sasaran bina lingkungan, penulis melihat bahwa PT Madubaru telah memberikan kontribusi kepada masyarakat sekitar, hanya saja kontribusi tersebut perlu untuk dimaksimalkan sehingga implementasi tanggung jawab sosia perusahaan dalam bentuk PKBL dapat memberikan manfaat besa bagi kedua belah pihak, khususnya kepada masyarakat sekitar. Upaya memaksimalkan dapat dilakukan dengan menata ulang berbagai kegiatan yang telah ditentukan, sehingga kebermanfaatan dapat lebih dirasakan.

Tidak ditemukan dampak negatif dari implementas tanggung jawab sosial perusahaan dalam bentuk PKBL tersebut. Hanya saja, penulis mendapati keterangan dari lapangan bahwa program bina lingkungan yang telah diberikan oleh PT Madubaru menjadi hambatan bagi beberapa warga yang menerima dampak negatif dari kegiatan usaha PT Madubaru untuk dapat menyampaikan keluh kesahnya atas dampak negatif tersebut Beberapa warga tersebut hanya menerima kondisi itu apa adanya.

\section{SIMPULAN}

Tanggung jawab sosial perusahaan yang diimplementasikan PKBL diwujudkan dengan pemberian pinjaman dan hibah serta dengan memberdayakan kondisi sosial masyarakat setempat. Pada pelaksanaan program kemitraan masih belum optimal karena belum semua mitra binaan memperoleh pembinaan. Padahal pembinaan yang seharusnya dilakukan tersebut dapat bermanfaat untuk meningkatkan produktivitas usaha bagi mitra binaan Produktivitas usaha tidak bisa hanya ditingkatkan melalui aspek penambahan modal kerja saja. Sedangkan pada program bina lingkungan yang diimplementasikan sebagian besar juga masih berupa pemenuhan kebutuhan sesaat, belum sampai pada aspek keberlanjutan sebagaimana yang dimaksudkan dalam community development.
Hambatan yang dihadapi oleh PT Madubaru dalam mengimplementasikan PKBL adalah sulitnya mencari usaha kecil yang sesuai dengan kegiatan usaha perusahaan, sulitnya mencari pelaku usaha yang bermental baik dan bertanggung jawab, serta tidak sepadannya alokasi anggaran untuk kegiatan PKBL dengan jumlah permintaan, sehingga dana yang digulirkan masih dirasa kecil oleh masyarakat.

Dampak dari implementasi PKBL belum optimal dirasakan, sebab meskipun PT Madubaru telah melaksanakan PKBL dalam berbagai kegiatan dan merasa ada hubungan baik dengan masyarakat setempat yang tercipta melalui implementasi PKBL tersebut, namun di sisi lain kemanfaatan yang dirasakan mitra binaan dan masyarakat sasaran belum optimal sebab belum sampai pada taraf memberdayakan masyarakat.

\section{DAFTAR PUSTAKA}

Azheri dan Isa Whyudi. 2008. Corporate Socil Reasponsibility: Prinsip, Pengaturan dan Implementas., Malang: In-Trans Publishing.

Gunawan Widjaja dan Yeremia Andri P. 2008. Risiko Hukum dan Bisnis Perusahaan Tanpa CSR. Jakarta: PT Percetakan Penebar Swadaya.

Kementrian Lingkungan Hidup dan Universitas Trisakti. 2011. Pedoman CSR Bidang Lingkungan. Jakarta: KLH dan Universitas Trisakti.

Undang-Undang Nomor 40 Tahun 2007 tentang Perseroan Terbatas.

Undang-Undang Nomor 20 Tahun 2008 tentang Usaha Mikro, Kecil dan Menengah.

Keputusan Menteri BUMN Nomor Kep-236/MBU/2003 tentang Program Kemitraan BUMN dan Bina Lingkungan. 
Surat Edaran Menteri BUMN Nomor SE-433/MBU/2003 tentang Petunjuk Pelaksanaan Program Kemitraan BUMN dan Bina Lingkungan.

\section{IDENTIFIKASI POTENSI EKONOMI PRODUKTIF} PARA LANSIA PENGHUNI PANTI WERDA

Oleh:

Sri Iswanti, Ariyadi Warsito, dan Kartika Nur Fathiyah Universitas Negeri Yogyakarta

\section{Abstrak}

Penelitian ini bertujuan untuk mengidentifikasi potensi ekonomi produktif pada para lansia penghuni Panti Wreda. Pendekatan penelitian yang digunakan adalah penelitian deskriptif kualitatif. Subjek penelitian dipilih dengan menggunakan teknik purposive sampling. Metode pengumpulan data menggunakan wawancara mendalam, observasi, dan dokumentasi. Analisis data menggunakan analisis kualitatif deskriptif. Hasil penelitian menunjukkan bahwa lansia di panti wreda memiliki banyak potensi yang dapat dikembangkan untuk kegiatan ekonomi produktif, akan tetapi di lapangan potensi ekonomi yang mengarah produktif belum teraktualisasi karena ketakutan pengelola bahwa produkitas beknmi produktif baha semakin men percepat pela bahwa aktivitas ekonomi produktif bahwa semakin mempercepat penurunan lansia dan ketakutan menyalahi aturan yang ada. Temuan lain adalah ada perbedaan pengelolaan antara panti yang berstatus negeri dengan yang berstatus swasta. Panti yang berstatus negeri pengembangan minat penghuni cenderung optimal karena pendanaan yang banyak ditopang dana dari pemerintah, sedangkan di swasta pengembangan minat maupun potensi lansia cenderung agak terabaikan karena dana lebih banyak ke operasional pemenuhan kebutuhan sehari-hari lansia.

Kata kunci : potensi ekonomi produktif, lansia

\section{PENDAHULUAN}

Dari tahun ke tahun persentase jumlah penduduk lansia semakin meningkat seiring dengan peningkatan pelayanan kesejahteraan khususnya kesehatan. Boedhi Darmodjo (1999: 2) menjelaskan bahwa diperkirakan di negara-negara berkembang sampai 30 tahun mendatang akan terjadi ledakan jumlah penduduk lansia sebesar 200-400 persen. Kondisi yang demikian memiliki 2 makna yang saling bertolak belakang, yaitu di satu sisi sebagai 